This sample of J. J. truthfulness is not so alarming; but to even grossly slander the Ferris wheel without any use or provocation whatever, shows a very mean disposition.

The letter of thanks which he states the Eppstein family wrote to him, is another myth. He wrote it himself and became so obtrusive to the family that they finally signed it to get rid of him. Any one doubting this may address B. Eppstein, 3144 Wabash Avenue.

No one who is acquainted with the Omnicura will find it strange that J. J. Russell does not want to be connected with this "new medical discovery." Imagine a string or piece of tape, joined at the ends and hanging loosely about the neck, with a number of little plasters attached to it, which are claimed to possess the miraculous power of drawing every known disease out of the system : curing Bright's disease, consumption and every ailment imaginable; this is the Omnicura. The price is $\$ 10$ and is based on profound psychologic reasoning. It is well known that a man who is swindled out of a quarter is apt to talk apout it; but when the amount is $\$ 10$ nothing but silence can keep him from ridicule.

This is the individual whom any physician in this city may meet some day at the bedside of a patient, telling the latter how badly he looks and how hopeless his case is without the Bracelin cure. In one case antitoxin has been used an hour or two before his intrusion-and his nostrum has cured diphtheria when antitoxin had failed. In another a patient is gradually recovering from pneumonia or some other illnessand he was cured by Russell after his physicians had given given him up.

Formerly a politician in Iowa, he now uses even physicians as willing or unwilling tools to advertise his nostrum; a fact which must bring a blush of shame to the face of every honest medical man. With overwhelming effrontery he has even brought a mandamus suit against Dr. Reilly, Chief of the Board of Health, because he was refused access to the daily reports of contagious diseases. When a physician resents his impudence he is made an example of in the Tribune, by being exposed to public ridicule. The name of Dr. Edwin Kuh, a man of the highest professional standing, is held up to every reader of Russell's pamphlet on the Bracelin cure, as a warning to others who might have the temerity to question its claims, in a letter refilled with new spelling, the main argument being, that Kuh means cow in English.

Quackery will exist as long as there are dupes among mankind, but it must be kept out of contact with legitimate medicine, the quack or his agent is as much out of place in a physician's office or at the bedside of his patients, as a prostitute in the home of a virtuous woman. Our legislation has made enough concessions to mountebanks, without physicians adding thereto. Legalize quackery as such is a well paying business and heeds no encouragement from medical men.

Martin Matter, M.D.

\section{The Wisconsin Diploma Mill.}

Office of Attorney General,

MADIson, Wis., June 13, 1896.

To the Editor:-Your Joursal of April 25 was forwarded to me by one of the good physicians of this State and furnished valuable information to this office for the purpose of bringing an action to dissolve the Wisconsin Eclectic Medical College at Milwaukee.

We have just prepared a complaint and I take great pleasure in forwarding a copy to you. You are at liberty to use it as you see fit. You will notice that $I$ have obtained leave from the Supreme Court of this State to bring an action to annul its charter. This action will be brought in Milwaukee county. I have to-day mailed the papers to the sheriff of that county requesting his service.

Yours truly,

W. H. MylreA, Attorney General.
STATE OF WISCONSIN,

Circuit Covrt for Milwauke County.

State of Wisconsin ex re W. H. Mylrea, Attorney General, Plaintiff, vs. The State of Wisconsin, upon the relation of its attorney general, ppectfully informs the Court

That the defendant, the Wisconsin Eclectic Medical College at Milwauke. is a corporation formally organized aud colorably existing under purpose of teaching students the seience of medicine and preparing and edueating them to practice as physicians, and conferring upon them, upon having been examined, and they having succeded in passof Dontor of Medicine, or such other degree which might be proper, aceording to their knowledge exhibited on such examination.

That the date of its supposed organization was on or about the 31st day of December, A.D. 1895, and in the preliminary papers preparatory to organization its principal oflice and place of business is stated to be the city of Milwaukee and county ot Milwankee aforesaid.

That heretofore, on the 27th day of May, A.D. 1896, upon the application of W. H. Mylrea, attorney geueral for the State of Wisconsin, it was by the consideration and judgment of the Supreme Court of said state of Wisconsin ordered that leave and permission be and they were then granted by suid Court to said attorney general to commence an action in the Circuit Court of Milwaukee County and State of Wisconsin, upon Medical College, to vacate its charter and annul its existence as a corporation, together with such other and further relief as to the Court may seem just and equitable.

And thereupon the State of Wisconsin, by its said attorney general, mlaining, shows to the court and alleges

That on the 23d day of December, 1695 , Fred Rutland, Ann Neve Rutland and $H$. Meyer associated together for the purpose of forming a corporation the object and busid

1. "For the purpose of teaching students the science of medicine and preparing and educating them to practice as physicians and conferring upon them, upon having been examined, and they having succeeded degree of Doctor of Medicine, or such other degree which may be proper, according to their knowledge exhibited on such examination.

2. "The name of such corporation shall be the 'Wisconsin Felectje
Medical College at Milwakee, and its location is in the City of Mil. waukee, County of Milwaukee and State of Wisconsin.

3. "This corporation is formed without capital stock.

4. "The general officers of this corporation shall consist of a president, a treasurer and a secretary, the oflice of secretary and treasurer may be held by one person.

5. "The Bourd of Directors shall consist of three persons who shall hold their office for five years and shall be elected by the members of
the corporation. The Directors shall have the general charge, coutrol the corporation. The Directors shall have the general charge, coutrol and management of the corporation, its affairs and property. Tie Presi-
dent shall preside at all meetings of the Board of Directors and of the members of the corporation; the secretary shall preserve the seal, ness incidental thend The Treas corporallon and atend to $t 11$ buslof the corporation and shall keep the accounts of the corporation and books belonging to it. Any of these ofticers may act for the other ofticer in the absence of the same, aud the office of secretary and treasurer may he filled by one person.

6. "Every person of good moral character having a diploma entitling him to practice as a physician may become a member of this corporation by a majority of the vote of the members of this corporation.

7. "Kegular meetings of the members of this corporation for the held annually ou the first Tuesday after the first day of Junuary of every year. 8. "The stgners of these articles are at the time of the signing thereof
the only members of the corporation. and the first meeting of the memabers thereof for the purpose required by law shall be beld at Room 7 of
Lipp's Block. City of Milwaukee and County of Milwaukee, on the 2 th day of December. 1895, at 3 o'clock in the afternoon.

Sald articles were signed by Fred Rutland. Ann Neve Rutland and $H$. Meyer, on the said $23 d$ day of December, 1895, recorded in the office of the Register of Deeds for Milwallee County. and on the 31st day of December, 1895, duly filed in the office of the Secretary of State of said te of Wisconsin

Complainant further complaining denies that he bas any knowledge or information sufficleat to form a belief as to whether or not a Board
of Directors for said corporation has ever been elected, or as to whether or not the person "H. Meyer," one of the alleged signers of said articles of incorporation. has any existence in fact.

Complainant alleges upou information and belief that no record has been kept of the meetings of the Board of Directors of suid corporation, if it has a Board of Directors, and that no by-laws bave been adopted by stid corporation, and that no record of any of the acts or doings of said corporation has been kept or preserved in any manner. That said corporation pretends to be carrying on the business of a medical college at tain rooms above a store building located at that place. which rooms are adapted for residence purposes only and are utterly unfit for the pur. pose of the business of carrying on a nedical college. That thid porporation has no apparatus or paraphernalia of any kind suitable for the carrying on of $t$ medical college, or for the giving of instruction therein. That it has uo medical library of any kind suitable for the use of teachers or students. That it employs no teachers to give instruction to perthe rights and privileges intended to be conferred upon ft by its articles of organization, and does not intend to exercise any of the rights and privileges so intended to be conferred upon it.

Complainant further alleges upon information and belief that said Fred Rutland, Ann Neve Rutland, the wife of said Fred Rutland, and said $\mathrm{H}$. Meyer, if there be a person by that name, did not organize said corporation in good faith for any of the purposes mentioned in its said articles of organization, but fraudulently aud unlawf ully organized said corporation for the sole purpose of enabling them to issue to ignorant and
unskilled and who!ly incompetent persons, spurious and bogus diplowas purporting to confer upon such persous the pretended authority of practicing medicine and surgery with intent thereby fraudulently to procure from such persons large sums of money in payment therefor.

Complainant further alleges upon information and belief that after said association had thus been formally organized in accordance with the laws of this State, the said Fred Rutland and Ann Neve Rutlaud,
bis wife, in futherance of the unlawful and fraudulent scheme aforesaid, 
procured from the Steretary of State of said State a certificate such as he is required by law to issue, certifying that there had been on the $31 \mathrm{st}$ day of December, 1 s95, filed in his Department "an instrument in writing, purporting to be articles of association of a corportion to be known as the Wisconsin Eclectic Medical College ht Milwakee, without capital college, etc., and that, therefore the State of Wisconsin did certify and rant unto the said Wisconsin Eclectic Hedical College th Milwaikee the powers and privileges conferred by Chapter $6 t^{\circ}$ of the Revised Statutes of the State of Wisconsin, and all acts amendatory thereof, for th purposes rbove stated, and in accordance with their said articles of association."

In witness whereof the said Secretary of State alfixed his baud and oflicial seal on the said 31st day of December, 1895 .

Complainant further alleges upon information and belief that thereafter Fred Rutland aud In Neve Rutiand, for the purpose of carrying out their fraudulent scheme as aforesaid, caused a large number of advertisements to be inserted in newspapers throughout this and other Strtes, and a large number of circulars soliciting persons to apply to it for diplornas and licenses such as would permit them to practice medicine and surgery in this and other states, shid advertisements and cir culars among other things stating in substance that if the applicant should be able to answer before a catar queseres a diploma to such persons which diplom would enable such person to protich of practice medteris of its authority to issue such diploma, and for the purpose of inducing persons to act upon these statements, said Fred Rutlapd and his wife woula send out with such circulars a copy of the certificate issued by circulars that the State of Wisconsin had satisfied itself that the purposes of the corporation were regular and in accordance with the law and had accepted a fee for incorporation and affixed its seal to the charter of said corporation, which charter declared the purposes and methods of the corporation, aud that the State thereby had sanctioned such purposes, and that therefore no person or power could disturb either said college or its graduates.

That by means of the authority apparently conferred upon said corporation by its articles of incorporation aud through said advertise ments and said circulars the said fred Rutlaud and wife have induced a great many persous to apply to them for aud to pay them considerable sums of money for such diplomas, and have issued a great mauy of such diplomas to such persons, who have made no preparation or study of either the scieuce of medicine or surgery, and who are wholly unfit and iucompetent to pructice either the science of medicine or surgery.

Complainaut denies that he has any knowledge or information sulficient to form a belief as to how many of such diplomas have been issued. but alleges that a large number of them have been issued, and

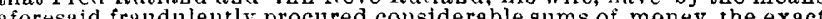
a foresti fruthe inount of what coliet that said Fred kund for euch of suid diplomas a sum varying from to to $\$ 0$, according to the orility of the apnlicant to pey for the eame ty of the applicant to pay for the a am

Complainunc alleges upon information and belief that not only was said corpotation organized as aforesuld solely for the purpose 0 described, but that said fraudulent business above described is now and will continue to be its ouly business so loug as said corporation shal ve perunitted to exist.

That the carrying on of said business is detrimental to the advance ment of the science of medicine and surgery, as well as contrary to good morals and public policy. That it directly tends to encourage ignorant, unscrupilous and wholly unfit persons to practice the important professions of medicine and surgery, therebr greatly endaugering the welfare and good health of many of the people of this State.

In thort. that the carrying on of said business by said corporation is clearly a wilful misuse and abuse of the privileges and franchises conferred upou it by its articles of incorporation.

WhEREFore, Complainaut prays the Court that it will vacate the charter aud and the existeuce of the said Wisconsin Eclectic Medica College at Milwankee. toether with such other and further relief as to the Cuturt may seem just and equitable.

\section{Medical Society of State of Pennsylvania.}

Harrisburg, PA., June 15, 1896.

To the Editor:-In your issue of May 30, page 1092, it is stated the "next convention will be held at Pittsburg in September, 1897." The next meeting of the Medical Society of the State of Pennsylvania will be held in Pittsburg, Pa., the third Tuesday of May, 1897. There was some mention of September, but May is provided for in the By-Laws. Convention is not a good word to use for meetings of medical men, though a good many journals use it, our JounN $A$ L should set a better example. The above correction of date and title is so you can have the list of meetings correct. Very truly,

W. T. Bishop, M.D.

\section{The Journal Itself}

New Castle, Ind., June 5, 1896.

To the Editor:- . . . . It is the best medical journal published, the best the Association has ever had, and improv ing weekly.

G. W. Burke, M.D.

Liberty, Mo., June 14, 1896.

To the Editor:-Allow me to compliment the Journal as one of the best in the United States.

J. M. ALLEN, M.D.
Chicago, June 6, 1896.

To the Editor:-In enclosing my vote, I take pleasure in asking to be allowed to thank you for your good work on our Journal. I think it is the high-class weekly for the general profession in the United States. Cordially yours,

Albert B. Hale, M.D.

Clyde, N. Y, June 12, 1896.

To the Editor:-With great pleasure I acknowledge the receipt of my much wished for copy of the Jounnal of Dec. 28,1895 . I am more than ever tenacious that there shall be no break, as, without tiattery, under the present editorial conduct, it is a library of itself, and the best medical journal now published.

I assume to be a competent judge, as I have been a reader of it since its first publication in the weekly form.

$$
\text { Yours truly, D. Colvin, M.D. }
$$

Cincinnati, June 5, 1896.

To the Editor:-I enclose to you my ballot, as also my check for $\$ 5$ for yearly dues.

Now, my dear Doctor, I want to thank you for your distinguished services as Editor of the JournaL. I think it ranks with the journals of the East.

The tone of the Journal is high. It firmly supports the Code. In my opinion, it will grow and grow, and show the world that no section can control the Western and Southern profession. Wishing you and the Journal all success, I am Yours truly, John A. MurPhy, M.D.

\section{PUBLIC HEALTH.}

Dr. Bond of Gloucester, Eng., sends us a copy of a useful leaflet drawn up by him and entitled "Our duty in regard to Vaccination, or fifteen reasons why we should believe in the efficacy of Vaccination as a Preventive of Smallpox." This might be distributed broadcast in those districts where recalcitrant Board of Guardians have failed to do their duty.

Low Sickness-Rate in the German Army.-It is pleasant now and then to put one's finger on a fact that sustains faith in the application of hygienic measures. The General Staff Surgeon of Prussia reports that by the energetic application of hygienic measures-which include vaccination and revaccination-the invaliding among troops has been reduced 42 per cent. since 1868 , and the mortality has been lessened 57 per cent., which means that two thousand men were alive at the end 1895 who would not have been had the former conditions obtained.

Schools and Disease; A Model Preventive System.-.Dr. Leslie McKenzie, the Health Officer for the Borough of Leith, refers in his annual report for 1895 to the system followed in the town for the better prevention of the spread of infectious dis. ease by the agency of 'schools. Each day an official of the School Board of Leith calls upon the health officer for the purpose of receiving lists of infectious cases notified to him, and then proceeds to distribute particulars to the different masters whose schools are interested in the cases, with the view of at once securing the absence from school of all children from an infected house until the house has been declared to be disinfected, etc., to the satisfaction of the health officer or some medical practitioner. Headmasters also notify to the School Board all cases of sickness coming to their knowledge, and thereupon similar steps are taken. The system is modeled on that obtaining at Glasgow, and gives satisfaction. Given the strict carrying out of the plan it ought to succeed.-British Medical Journal.

Annual Death Rate in Peru.--Odriozola's address at the Commencement of the University at Lima, contains the statement that the annual death rate at Peru is from 35 to 40 per thousand, of which a third is due to tuberculosis, while many of 